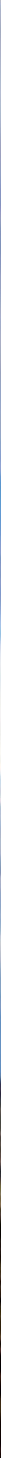

La Peña de los Enamorados sobre la vega de Antequera. Foto: José Manuel Blanco. Fuente: Conjunto Arqueológico Dólmenes de Antequera 


\section{Vega de Antequera y Archidona}

José Ramón Menéndez de Luarca Navia Osorio, arquitecto-urbanista
La Peña de los Enamorados, uno de los hitos más singulares del paisaje andaluz, domina la fértil vega de Antequera y Archidona, dos notables centros históricos que encuentran en la Peña su nexo de unión y, a la vez, la frontera de una tan secular como cordial rivalidad.

Los tres elementos mencionados: la Peña, como representante de un conjunto de elevaciones montañosas presididas por la espectacular formación caliza del Torcal, la planicie de la vega y los asentamientos urbanos, dotados de un rico patrimonio histórico, configuran un paisaje excepcional, tanto por el atractivo de los rasgos que lo constituyen, como por su centralidad en la estructura territorial andaluza.

Al papel de centralidad que la vega ha asumido como nudo de intersección entre las principales vías de comunicación de la región, se superpone la condición fronteriza, una condición mantenida desde sus orígenes. En efecto, el nítido contraste entre la planicie de la vega y las formaciones montañosas que la encierran se generó geológicamente por el choque entre las placas europea y africana. Dentro de las vicisitudes de ese enfrentamiento entre continentes la conexión entre las masas de agua del Mediterráneo y el Atlántico experimentó diversas alternativas hasta alcanzar el paso actual entre las columnas de Hércules que flanquean el estrecho de Gibraltar. En un cierto momento, la comunicación se establecía por un canal dispuesto al norte del cordal subbético. En el proceso orogénico posterior ese pasillo marino sufrió un alzamiento y la continuidad del corredor se fragmentó en un rosario de mares interiores que se sucedian desde la Bahía de Cádiz al oeste, hasta la vega de Murcia y Cartagena pasando por las de Antequera, Granada y Guadix. Una secuencia de espacios fértiles que siguen conformando una vía natural de comunicación, ahora terrestre, entre los dos mares.

Tras un largo proceso erosivo, el mar interior que conformaba la hoy vega de Antequera y Archidona consiguió abrirse paso a través de la muralla caliza de serranía subbética por la estrecha hendidura del desfiladero de El Chorro. Lo abrupto y especta- cular del tajo lo hizo aparecer como una obra titánica que se llegó a relacionar con el mito de Hércules. Como restos del antiguo mar aún permanece una serie de lagunas endorreicas, cuyo ejemplo más notable, la Fuente de Piedra, sigue ofreciendo un magnífico paisaje lacustre y una reserva de salinas que muestran su origen marino.

Los límites del antiguo lago muestran una fuerte disimetria, mientras el límite meridional se configura por una abrupta alineación de elevaciones presididas por la mole del Torcal; hacia el norte se cierra por dos brazos montañosos que se aproximan en sus extremidades: las sierras de Los Caballos y de Arcas; entre ambas, el cerro de La Camorra define dos amplias aperturas hacia el suave paisaje de campiña del valle del Guadalquivir.

Lo peculiar de ese cinturón montañoso es que su carácter abrupto contrasta con su escasa profundidad, de forma que entre sus picos más altos deja una serie de pasos de relativo fácil tránsito desde las ensenadas de Málaga y Vélez Málaga en el Mediterráneo hacia el interior de la península. La vega goza así de una accesibilidad privilegiada frente a la impenetrabilidad de los profundos macizos montañosos que la flanquean por oriente y occidente: la Serranía de Ronda y el altiplano de Loja.

El conjunto de rasgos naturales descritos conducen a la configuración de un paisaje tan privilegiado como singular. Desde el punto de vista de la accesibilidad, en él se produce el entrecruzamiento de corredores naturales de largo recorrido: de este a oeste y de norte a sur. Por lo que se refiere a la fertilidad, la planicie de la vega ofrece suelos profundos y bien irrigados. La coexistencia de la llanura con el cinturón montañoso que la protege ofrece la posibilidad de frescos pastos de verano que refuerzan su potencial ganadero. También desde el punto de vista minero, la abundancia de sal y los diversos tipos de rocas refuerzan las favorables condiciones del lugar. Por último, queda referirse al fuerte contraste entre la amplia llanura de la vega y la verticalidad de los riscos que la cierran que lo singulariza frente a los territorios vecinos. Es un paisaje destacado por la claridad, por la nítida distinción entre 
Al papel de centralidad

que la vega ha asumido

como nudo de intersección

entre las principales vías de

comunicación de la región,

se superpone la condición

fronteriza, una condición

mantenida desde sus

orígenes

figura y fondo. No es de extrañar que tan favorables condiciones naturales hayan propiciado a lo largo de la historia la continua aparición de hechos culturales de primer orden hasta llegar a conformar un paisaje de extraordinaria complejidad.

Desde el inicio la riqueza vegetal y faunística atrajo a las primitivas sociedades de cazadores y recolectores, para quienes los collados de entrada al valle constituian pasos obligados donde sorprender a sus presas. En uno de esos lugares, en el margen del puerto de Málaga, se creó, en la Cueva de Ardales, el santuario de pintura paleolítica más rico y extenso del sur de la península.

La paulatina introducción de la ganaderia y la agricultura que caracteriza a las civilizaciones del neolítico y el calcolítico se corresponde con unos nuevos modos culturales. La marcación del paisaje que suponemos se propone realizar el arte rupestre del neolítico-calcolítico encuentra un soporte privilegiado en la citada nitidez del peculiar paisaje de la vega de Antequera y Archidona. En efecto, ni la monótona sucesión de colinas redondeadas de la cuenca del Genil o de la campiña del Guadalquivir que confinan la vega por el norte, ni el intrincado paisaje erosivo de los montes de Málaga por el sur, presentan las condiciones adecuadas para la señalización de hitos paisajísticos diferenciados y de amplia visibilidad.

Frente a la marcación de hitos naturales preexistentes, que caracteriza al arte rupestre, las arquitecturas megalíticas plantean una estrategia alternativa, la de creación "ex novo" de un hito, generalmente en zonas de paisaje menos prominentes. La monumentalidad sin parangón de los monumentos antequeranos de Menga, Viera y El Romeral es la mejor muestra del excepcional desarrollo inducido por la explotación de los recursos del lugar.

Con la implantación de la cultura del bronce, una sociedad más bélica y jerarquizada tiende a ocupar lugares prominentes, de más fácil defensa, lo que supone la elección de emplazamientos escarpados que mantendrán ese uso en la historia subsiguiente: Castillejos de Teba, Ardales, Castillón de Singilia, Peña de los Enamorados, Aratispi.
La llegada de los pueblos del mediterráneo oriental, fundamentalmente fenicios $y$, en menor medida, griegos, a las ensenadas costeras, se acompaña con la introducción de nuevos cultivos como el olivo y la vid que, junto al trigo, constituyen la tríada mediterránea que dominará el paisaje agrario posterior. Los hábitos comerciales de los nuevos colonizadores dan lugar a activas relaciones de intercambio con los pueblos del interior, con lo que se contribuye a la paulatina constitución de una sociedad más urbanizada. La inusitada dimensión de la muralla ibérica que circunda la hoya de Archidona es buena muestra de la riqueza de sus constructores. Tales circunstancias implican un fortalecimiento de las rutas de largo recorrido, tanto las que unen las Ilanuras agricolas interiores con las ensenadas portuarias de Vélez Málaga y Málaga como las que discurren por el corredor este-oeste.

La dominación romana supuso una fuerte intensificación de la explotación del territorio promovido por la creciente demanda de la metrópoli. Sobre la base de la excepcional riqueza agraria, salinera y minera de la comarca se crea una densa ocupación de las áreas más fértiles mediante una dispersión de villae en las que el olivo se configura como absoluto protagonista del flujo exportador. Una intensificación agraria lograda mediante la generalización de los sistemas de regadío que propicia el desarrollo de prósperas ciudades, como Singilia y Anticaria. Prueba del nivel alcanzado son las exquisitas obras escultóricas alli aparecidas, como el famoso Efebo de Antequera.

La irrupción de los pueblos germánicos supuso el establecimiento de una condición fronteriza a lo largo del cordal subbético, que separaba el dominio mediterráneo bizantino de las tierras visigóticas del interior. Una condición fronteriza que se mantendría, salvo pequeños intervalos, en el milenio posterior.

Con la dominación islámica la comarca antequerana forma parte de la cora (demarcación provincial) de Raya con un centro principal en Archidona que disputa a Málaga la capitalidad. El dominio del territorio se distribuye entre los nuevos habitantes, ocupando las estirpes árabes la llanura y los bereberes norteafricanos las áreas montañosas.

Si en los periodos precedentes la característica de la zona como lugar de paso y cruce de caminos había sido enfatizada como promotora de intercambios, ahora se va a configurar como un persistente espacio de frontera, acompañado de continuos conflictos bélicos, traducidos en un acelerado proceso de fortificación del territorio.

El largo conflicto protagonizado por Umar Ben Hafsun a caballo de los siglos IX y X enfrenta la población mozárabe y muladi de la comarca con el poder central cordobés. Como consecuencia, ambos bandos contienden en la elevación de grandes alcázares fortificados en las antiguas ciudades, como Antequera y Archidona, Ardales, Teba y Cañete, pero también en otros puntos prominentes con especiales características defensivas, entre los que destaca Bobastro. El conjunto formado por las iglesias rupestres 

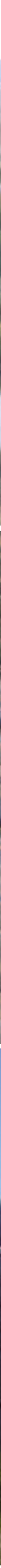

1. Desfiladero de El Chorro.

Foto: José Ramón Menéndez de Luarca

3. Dolmen de Menga.

Foto: Javier Pérez González. Fuente: Conjunto Arqueológico Dólmenes de Antequera

5. La vega de Antequera desde lo alto de la Peña de los Enamorados.

Foło: Aurora Villalobos. Fuente: Conjunto Arqueológico Dólmenes de Antequera

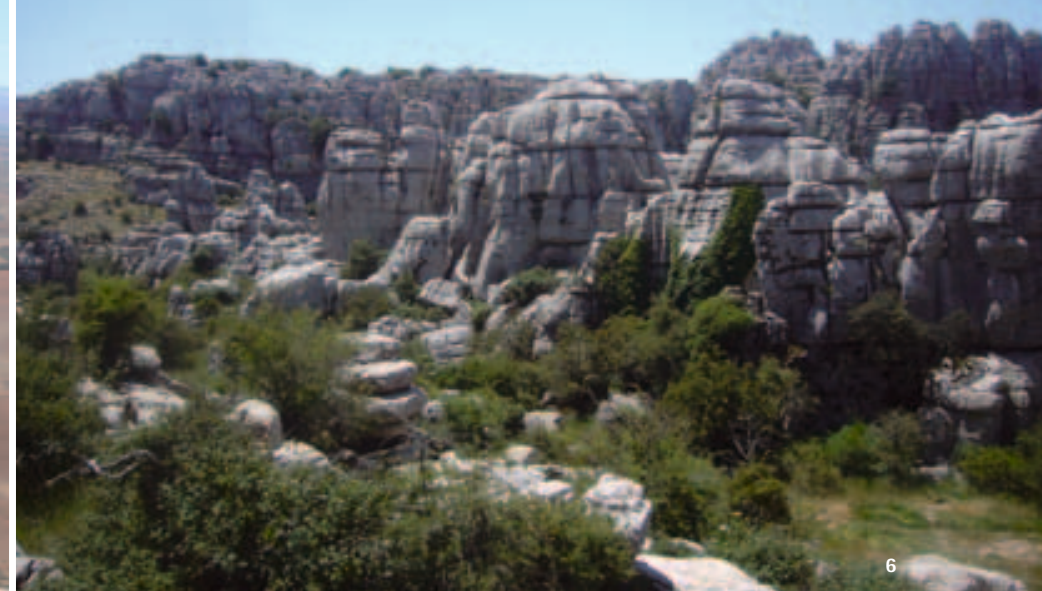

2. Laguna de Fuente de Piedra

Foto: José Ramón Menéndez de Luarca

4. Vista de Archidona con la plaza octogonal.

Foto: José Ramón Menéndez de Luarca

6. Vista del Torcal.

Foto: José Ramón Menéndez de Luarca 


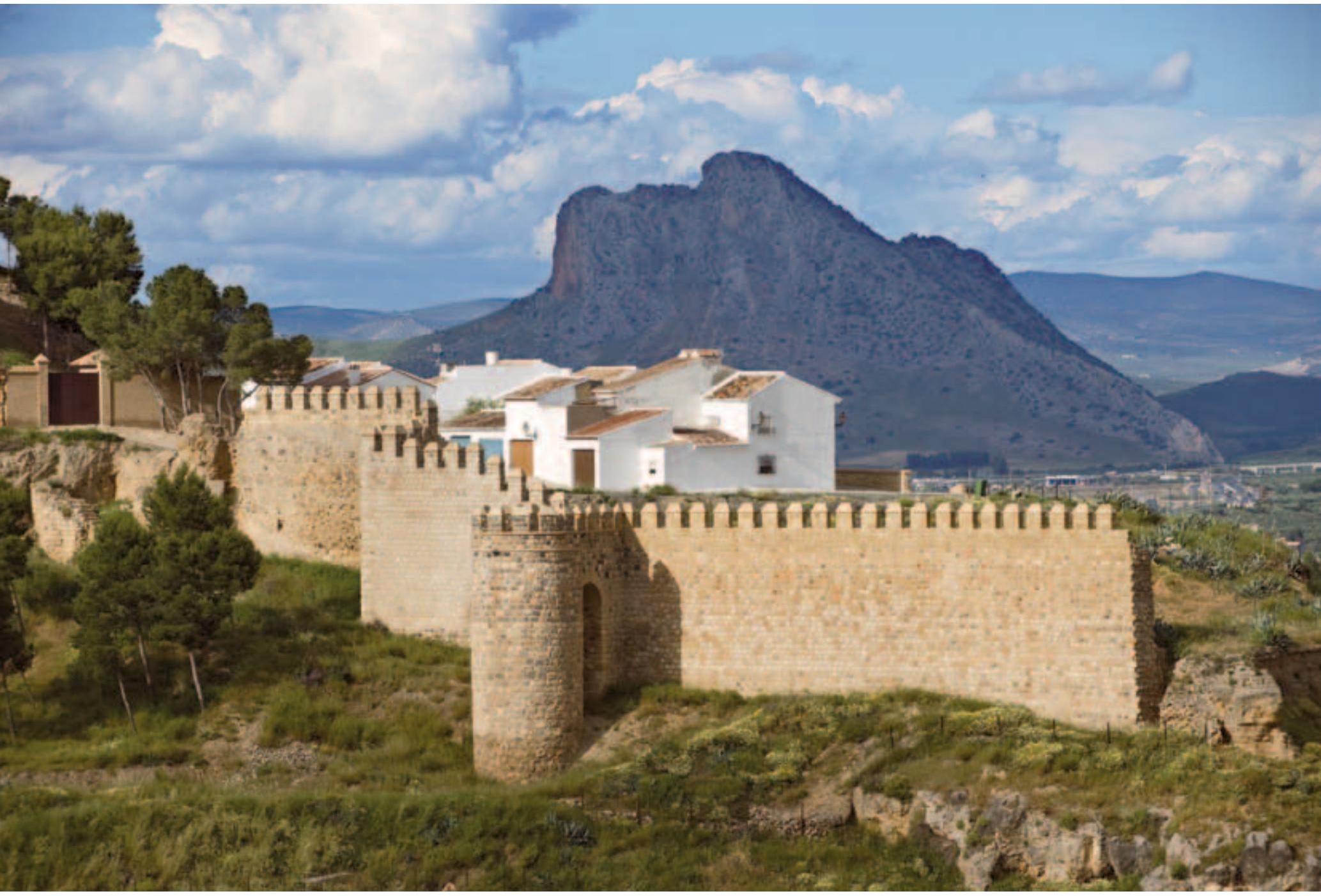

Muralla de la Alcazaba de Antequera. Foto: Juan Carlos Cazalla, IAPH

y las obras defensivas en tan espectacular risco conforma uno de los paisajes más singulares del ámbito.

El avance de la reconquista en el XIII y el consiguiente aislamiento del reino granadino endurecen las condiciones bélicas de frontera. Se asiste a un proceso generalizado de encastillamiento mediante la erección de un sistema de torres vigía o almenaras, hachos en la versión romance, que ocupan algunos riscos inaccesibles de gran proyección paisajística, como ocurre con las de Aznaraz o Zambra.

En cualquier caso, y a pesar de la constricción bélica, se asiste a una intensificación de los sistemas agrarios de regadio, en las proximidades del ámbito protegido de las ciudades, como ocurre en los ruedos de Antequera y Archidona.

La conquista cristiana fue acompañada en las tierras de Antequera por la expulsión total de la población precedente, lo que supuso una ruptura en las tradiciones que regulaban en el manejo del espacio. Tras la conquista definitiva de Granada se establecen las bases para un súbito florecimiento de la comarca, manifiesto en la proliferación de nuevas villas. Si la situación anterior de las medinas venía condicionada por las necesidades defensivas, ahora las villas nuevas, como la de Campillos, buscan su localización en las Ilanuras más fértiles. En general, se trata de poblaciones planificadas según una malla rectangular, de gran interés, por constituir un precedente del modelo que se generalizará en la sucesiva colonización americana.

Otro rasgo significativo para la reorganización territorial fue la especialización ganadera de los nuevos conquistadores. Para facilitar el movimiento de los rebaños se dispuso una densa malla viaria de cañadas, o realengas, de corto y largo recorrido, que ocupan viejas sendas inmemoriales. De este modo, se viene a reforzar el papel central de Antequera, como cruce de rutas y centro comercial. A su vez, el desarrollo de la industria del tejido, asociado a la producción de lana, estimula el crecimiento de la zona. Testigo de tal desarrollo es el inusitado esplendor del barroco en las iglesias, palacios y plazas públicas de Antequera y Archidona.

Tras un periodo de decaimiento, entre 1910 y 1980, el área experimenta un súbito crecimiento a partir de su configuración como nudo de comunicaciones andaluz. El hacer compatible tal dinamismo urbano con una adecuación a las condiciones naturales y a su rica elaboración cultural a lo largo de la historia constituye el reto a afrontar en el futuro. 